Rapp. Grønlands geol. Unders. 103, 25-29 (1981)

\title{
Helvine from the Ilímaussaq intrusion
}

\author{
Ole Johnsen and Henning Bohse
}

\begin{abstract}
Introduction
Beryllium minerals are widespread in the Ilímaussaq intrusion. At present, 13 different beryllium minerals have been identified. These are bertrandite, gelbertrandite, spherobertrandite, beryllite, chkalovite, leucophane, epididymite, eudidymite, sorensenite, tugtupite, genthelvite (Semenov, 1969; Engell et al., 1971), semenovite (Petersen \& Rønsbo, 1972) and now helvine.

While epididymite occurs as an accessory in the alkali granite (Hamilton, 1964), chkalovite in pegmatites and hydrothermal veins (Engell et al., 1971; Semenov, 1969), all the other recorded beryllium minerals have been found in hydrothermal veins and alteration zones. Engell et al. (1971) reported that leucophane occurs as an accessory in the naujaite referring to the original description of Bøggild (1905). However, this description does not indicate whether the leucophane occurs as an accessory in unaltered naujaite or if it is related to veins cutting naujaite as recorded by Semenov (1969).
\end{abstract}

\section{Occurrence}

During the 1969 field season helvine was found in several pegmatitic pockets in the kakortokites, where it was misidentified as genthelvite (Bohse et al., 1971). These pockets occur in white kakortokite layer number +16 (fig. 1, locality A) at an altitude of $425 \mathrm{~m}$.

Pegmatites of this type but without observable helvine are common in the $+4,+7$ and + 16 layers of white kakortokite. The restriction of these pegmatites to the white kakortokite layers may be due to the looser packing and larger proportions of intercumulus material in the white than in the red and black kakortokite layers. This may have facilitated the migration of the late stage melts or fluids, which may have formed these pegmatites.

The central parts of the pegmatitic pockets are loosened by weathering and now occur as numerous boulders covering areas of $2 \times 5 \mathrm{~m}$. Some material still remains in place and is the basis for the following description.

The pegmatitic pockets rarely exceed a few metres in length and are irregularly lenticular in shape with a rather sharp contact towards the kakortokites. The contact is non-intrusive and the pegmatites do not possess a chilled margin. The outer margin is defined by aegirine needles overprinting the surrounding kakortokite structure. The radiating needles of aegirine, up to $2 \mathrm{~cm}$ in length, constitute the marginal zone of the pockets. The core of the pegmatite pockets is composed of large white tabular grains of microcline measuring up to 5 $\times 20 \mathrm{~cm}$. The microcline often has inclusions of prismatic aegirine. Irregularly shaped 


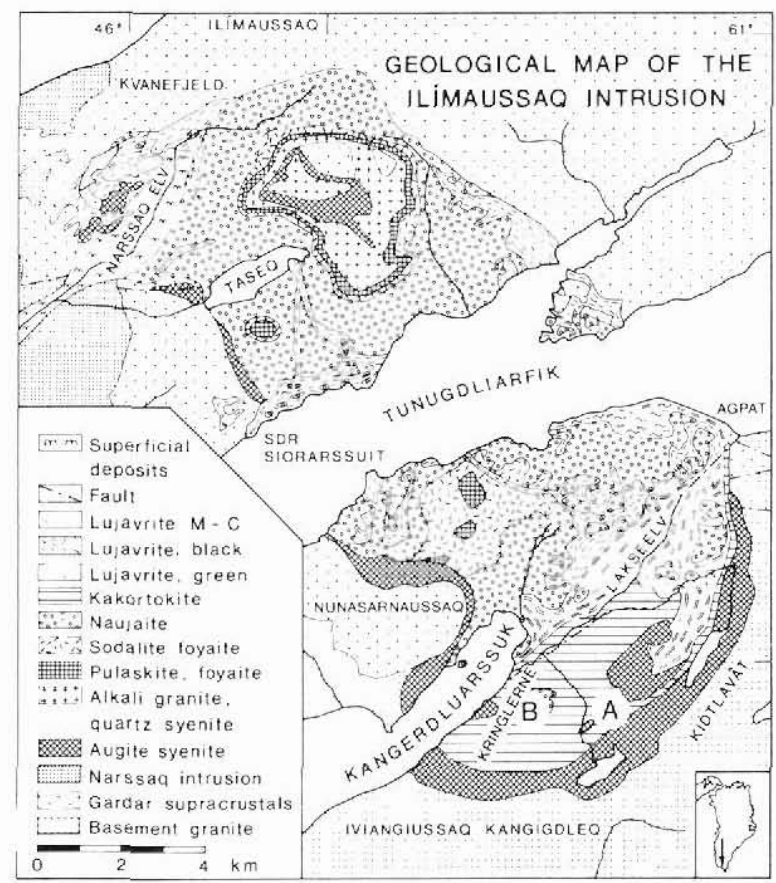

Fig. 1. Simplified map of the Ilimaussaq intrusion showing the localities of helvine discussed in the text.

masses of felt-like aegirine (up to fist size) occur between the microcline masses together with minor amounts of natrolite, green fluorite, Li-mica, chlorite, sphalerite and helvine.

In 1972 S. Karup-Møller (personal communication) found helvine as an accessory mineral in pegmatite bodies in white kakortokite, layer number +4 , at an altitude of $305 \mathrm{~m}$ (fig. 1 , locality B). These pegmatites are small irregular lenses, a few metres long, composed of coarse arfvedsonite and microcline with minor amounts of albite and aegirine. This locality was re-examined by one of us (H.B.) in 1978 and the above features confirmed. Several features indicate that the two helvine-bearing pegmatites are similar in origin. The marginal zone of aegirine needles, the central mass of microcline, and the felt-like aegirine, natrolite, sphalerite and helvine are common to both pegmatites. The pegmatites from the second locality, however, have generally suffered more hydrothermal alteration, and acmite is quite commonly developed. Blue apatite has also been noted from this locality.

Since the irregularly lenticular pegmatite bodies contain remnants of kakortokite minerals and structure, they are believed to be replacement bodies. No fracturing or deformation of the kakortokite, or crushing of the karkortokite minerals, has been seen.

\section{Mineralogy}

The helvine forms honey yellow grains up to four centimetres in diameter. In rare cases crystal faces can be seen, but no crystal forms can be determined. Like the microcline in the pegmatitic pockets helvine is filled with inclusions of needles and long prismatic crystals of aegirine. 
Table 1. Composition, density, refractive index and unit cell dimension of helvine from the Ilimaussaq alkaline intrusion

\begin{tabular}{|c|c|c|}
\hline & wt: & \\
\hline $\mathrm{SiO}_{2}$ & 32.25 & \\
\hline $\mathrm{BeO}$ & 12.79 & \\
\hline $\mathrm{Al}_{2} \mathrm{O}_{3}$ & 0.01 & $d_{\text {meas. }}=3.25 \mathrm{~g} / \mathrm{cm}^{3}$ \\
\hline FeO & 0.70 & \\
\hline Mno & 48.33 & $d_{\text {calc. }}=3.28 \mathrm{~g} / \mathrm{cm}^{3}$ \\
\hline zno & 2.57 & \\
\hline Mgo & $<0.01$ & $=1.733(1)$ \\
\hline $\mathrm{CaO}$ & $<0.01$ & \\
\hline$s$ & 5.74 & $\mathrm{a} \quad=8.282(2) \AA$ \\
\hline \multirow[t]{2}{*}{$\mathrm{H}_{2} \mathrm{O}$} & n.d. & . \\
\hline & 102.39 & Formula normalized to $13(0+5)$ : \\
\hline \multirow[t]{2}{*}{$0 \equiv$} & 2.86 & $\mathrm{Mn}_{3.84^{\mathrm{zn}}} \mathrm{n}_{0.18^{\mathrm{Fe}}} 0.05^{\mathrm{Be}} 2.88^{\mathrm{Si}} \mathrm{i}_{3.02^{\mathrm{O}}} \mathrm{O}_{1.99^{\mathrm{S}}} \mathrm{s}_{1.01}$ \\
\hline & 99.53 & \\
\hline
\end{tabular}

GGU Sample 150125

The chemical and physical properties, as shown in Table 1 , were determined on sample GGU 150125. The chemical analysis was performed using electron microprobe and atomic absorption (for Be only); the operation conditions and correction procedures for the microprobe data are described by Pedersen et al. (1975). The formula, normalized to $13(\mathrm{O}+\mathrm{S})$, shows that the GGU 150125 helvine is an almost pure end-member in the series: helvine $\left(\mathrm{Mn}_{4} \mathrm{Be}_{3} \mathrm{Si}_{3} \mathrm{O}_{12} \mathrm{~S}\right)$, genthelvine $\left(\mathrm{Zn}_{4} \mathrm{Be}_{3} \mathrm{Si}_{3} \mathrm{O}_{12} \mathrm{~S}\right)$ and danalite $\left(\mathrm{Fe}_{4} \mathrm{Be}_{3} \mathrm{Si}_{3} \mathrm{O}_{12} \mathrm{~S}\right)$.

An X-ray powder pattern of GGU 150125 was obtained with a Guinier-Hägg focussing camera, using $\mathrm{Cu} \mathrm{K}_{\alpha}$ radiation and quartz as internal standard. The refined cell parameter is: $a=8.282(2) \AA$. The density, determined by suspension in heavy liquids, is $3.25 \mathrm{~g} / \mathrm{cm}^{3}$, which is in good agreement with the calculated value of $3.28 \mathrm{~g} / \mathrm{cm}^{3}$. The refractive index was measured in sodium light to be $n_{\mathrm{D}}=1.733(1)$.

The relations between composition, density, refractive index and unit cell dimension found by Glass et al. (1944) and extended by Deer et al. (1963) are confirmed by the present data. Essentially pure helvine minerals like the present helvine are found in different associations (Dunn, 1976), including nepheline syenite pegmatites at St. Hilaire, but the Ilímaussaq helvine is distinguished by an unusually high $\mathrm{Zn} / \mathrm{Fe}$ ratio. 


\section{Genesis}

The average beryllium content of the Ilímaussaq agpaitic rocks, based on 16 analyses by Hamilton (1964) is $30 \mathrm{ppm}$ Be. This is in accordance with the $28 \mathrm{ppm}$ Be (Ferguson, 1970) and the $31 \mathrm{ppm} \mathrm{Be}$ (Gerasimovsky, 1969) in the weighted kakortokite average.

The Be contents of llímaussaq rocks and rock-forming minerals suggest that much of the $\mathrm{Be}$ in the rocks is not held by the rock-forming minerals. It could reside in accessory phases or in thin films on the surface of the rock-forming minerals, but this problem has not yet been investigated.

Since the pegmatites appear to be replacement bodies, it is possible that some of the $\mathrm{Be}$ in the pegmatite may have been directly derived from the pre-existing kakortokite. However, it is not clear whether the replacing fluids were themselves Be-rich residual kakortokite magmas or if their high Be contents stem from the leaching activity as they migrated to this particular locality.

Semenov (1969) pointed out that $\mathrm{Be}$ has the greatest mineral-forming capacity of all elements at Ilímaussaq, i.e. the ratio of the number of $\mathrm{Be}$ minerals divided by the $\mathrm{Be}$ clarke for the massif is maximal. This probably arises from the high solubility of Be in the alkaline volatile melts at Ilímaussaq, particularly the residual melts which led to pegmatite formation, and also the ability of Be to form complex ions. On this basis, the appearance of helvine in the kakortokite pegmatites, like the appearance of chkalovite in the naujaite and $\mathrm{M}-\mathrm{C}$ lujavrite pegmatites, is a result of $\mathrm{Be}$ concentration in residual magmas.

Acknowledgements. G. Asmund is thanked for the Be analysis. The Danish Natural Science Research Council provided the microprobe facilities.

\section{References}

Bohse, H., Brooks, C. K. \& Kunzendorf, H. 1971: Field observations on the kakortokites of the Ilímaussaq intrusion, South Greenland. Rapp. Grønlands geol. Unders. 38, 43 pp.

Bøggild, O. B. 1905: Mineralogia Groenlandica. Meddr Grønland 32, 625 pp.

Deer, W. A., Howie, R. A. \& Zussman, J. 1963: Rock-forming minerals. 4: Framework silicates. London: Longmans, $435 \mathrm{pp}$.

Dunn, P. J. 1976: Genthelvite and the helvine group. Mineralog. Mag. 40, 627-636.

Engell, J., Hansen, J., Kunzendorf, H. \& Løvborg, L. 1971: Beryllium mineralization in the Ilímaussaq intrusion, South Greenland, with description of a field beryllometer and chemical methods. Rapp. Grønlands geol. Unders. 33, 40 pp.

Ferguson, J. 1970: The significance of the kakortokite in the evolution of the llimaussaq intrusion, South Greenland. Bull. Grønlands geol. Unders. 89 (also Meddr Grønland 190,1) 193 pp.

Gerasimovsky, V. I. 1969: Geochemistry of the Ilimaussaq alkaline massif (in Russian). Moscow: Nauka, 174 pp.

Glass, J. J., Jahns, R. H. \& Stevens, R. E. 1944: Helvite and danalite from New Mexico and the helvite group. Amer. Miner. 38, 163-191.

Hamilton, E. J. 1964: The geochemistry of the northern part of the Ilímaussaq intrusion, S.W. Greenland. Bull. Grønlands geol. Unders. 42 (also Meddr Grønland 163,10) 104 pp.

Pedersen, A. K., Engell, J. \& Rønsbo, J. G. 1975: Early Tertiary volcanism in the Skagerrak: new chemical evidence from ash-layers in the mo-clay of northern Denmark. Lithos 8, 255-268. 
Petersen, O. V. \& Rønsbo, J. G. 1972: Semenovite - a new mineral from the Ilímaussaq alkaline intrusion, South Greenland. Lithos 5, 163-173.

Semenov, E. I. 1969: Mineralogy of the Ilímaussaq alkaline massif (in Russian). Moscow: Nauka, $165 \mathrm{pp}$.

O.J.,

Geologisk Museum,

Øster Voldgade 5-7,

DK-1350 Copenhagen $\mathbf{K}$.

H.B.

Institut for Petrologi, University of Copenhagen

$\emptyset$ ster Voldgade 10, DK-1350 Copenhagen $K$. 